\title{
Banks' Profitability in an Islamized Financial System: Comparative Study between Iran and Sudan
}

\author{
Eng. Ahmad Al-Harbi PhD \\ Budget Specialist \\ Finance Department \\ Ministry of Economy and Planning, Saudi Arabia \\ E-mail: aalharbi@mep.gov.sa
}

\begin{abstract}
The main objective of this paper is to explore and compare the drives of banks' profitability in Iran and Sudan as both countries Islamized their financial systems, and according to the best of my knowledge is the first paper to compare banks' profitability on the only two Islamized financial systems in the world, Iran and Sudan. This study employs panel data techniques specifically one-way fixed effect model, data obtained from Bank scope database, to address this paper title for the period I992-2008. The descriptive statistics results show that Iranian banks are more profitable and have higher loan to total asset ratio in comparison to Sudanese banks. Contrary, Sudanese banks are more liquid; more capitalized and have higher reserves. The regression analysis reported that capital adequacy (positive), loan intensity (negative), management efficiency (negative), lagged GDP growth (positive) and real interest rate (positive) had the same significant effect on banks' profitability in Iran and Sudan. Meanwhile, liquidity albeit had the same positive effect on banks' profitability in Iran and Sudan the results were significant in case of Iran. On the other hand, size, credit risk and industry concentration had opposite effect on banks in Iran and Sudan. The effect of size was negative for Iranian banks and positive and insignificant for Sudanese banks. Also, credit risk was negative and significant for Iranian banks and positive for Sudanese banks (insignificant). The same applies for industry concentration as the variable impacted Iranian banks negatively (significant) and Sudanese banks positively (significant).
\end{abstract}

Keywords: Islamic bank, Profitability, Comparison, Sudan, Iran, Islamized Financial System.

\section{Introduction}

Islamic banking practices dates back to the early days of Islam I400 years ago. These practices thrived until the $\mathrm{I} 2^{\text {th }}$ century BC when the Islamic civilization began to decline. This paved the way for the adaptation of Western financial model in the $19^{\text {th }}$ century. This trend continued in all Islamic countries until the middle of the $20^{\text {th }}$ century when the calls to establish Islamic financial institutions took momentum. Local savings banks which established in Egypt in 1963 considered the first banks without interest in Islamic countries. This trend continued in all over the world, the most important milestones of Islamic banking industry illustrated in Table I. The Islamization of the financial systems in Iran and Sudan considered another landmark for Islamic finance industry, this will be discussed below.

Iran: according to Khan and Mirakhor (1990), the Islamization of the banking system in Iran has gone through three phases. The period from 1979 to 1982 marked the first phase, when the banking system nationalized, restructured, and reorganized. The second phase began in 1982 and lasted until 1986. The defining events in this period were the approval of the Usury-Free Banking Operation Law on September I, 1983, and its implementation on March 21, 1984. The third phase began in 1986 and continues today. The Usury-Free Banking Law was enacted 3 years after the war with Iraq broke out. The banks were given I year from the date of the law's passage to convert their deposits to the new system and 3 years to convert all other operations.

However, the Iranian banking system under the dictum "Quia enim necessitas non habet legem, set ipsa sibi facit legem” started to deal with interest as on January 15, 1992, the Money and Credit Council, at its 758th session, in order to create a safe and secure investment environment, decreed that: "[T] he granting of any kind of benefits and profits such as guaranteed profit, provisional profit, $[. .$.$] are clear examples of banking, monetary and credit activities that banks and credit$ institutions who are authorized by the Central Bank of the Islamic Republic of Iran are permitted to do” (Hosseini 20I5). Moreover, Art. 2I of banks regulations allow banks to pay provisional profit ${ }^{\mathrm{I}}$ in particular circumstances to its depositors/customers. Thus, it can be said that the Iranian government did not eliminate riba (interest) from its financial

I"Provisional profit is a predetermined and fixed amount of money paid prior to the expiration of the ennealogy Islamic contract period and calculation of final profit (or loss)”. Mir (2002) cited in Hosseini (2015). 
system.

Currently, there are three commercial banks owned by the government, twenty private banks, and five specialized government banks.

Regarding the Iranian economy, upper-middle-income, it is the second largest economy in MENA region after Saudi Arabia and like Saudi Arabia its economy depend to large extent on oil revenues but Iran has the second largest population (approximately 80 million) in the region after Egypt. However, the country has high level of unemployment rate and poverty as well high inequality.

Sudan: the idea to Islamize the Sudanese financial system initiated when Omdurman University introduced the subject of having an Islamic economy as the primary method of business in 1966 (Chowhound, cited in Al-Sindi 2007). At the time, such a system was not implemented because the idea faced too many obstacles and opponents.

However, the idea of Islamic banking was revived when Prince Mohammad Al-Fisal met with President Jaffar Numairi in February 1976 and requested that he establish an Islamic bank (he did, and it was called Faisal Islamic Bank of Sudan; Al-Sindi 2007). Later, in 1977, the bank was established as a public limited company by a special act of parliament, the Company Act of 1925 (Stianse 2004, p. I56). This act marked the first step in Islamizing all Sudanese banks. The rapid growth of Faisal Islamic Bank of Sudan indicates that it has had support from both the government and the public. The bank's equity increased by more than $350 \%$ from 1979 to 1982, and the bank's average growth rate was $70 \%$ in the same period, and this growth led to the bank having much more capital than the other commercial banks (Stianse 2004, p. I56).

The success of Faisal Islamic Bank of Sudan in this short period triggered the establishment of more Islamic banks. In mid-I983 three Islamic banks were established: Al-Tadamun Islamic Bank, Sudanese Islamic Bank, and Islamic Co-operative Development Bank (Al-Sindi 2007). One year later, Al-Baraka Bank and Islamic Bank of Western Sudan were established; the latter changed its name twice, first to Alghareb Islamic Bank and then to Export Development Bank on January I5, 2003. Also, the Civil Administrative Act, which stipulated that no court in the country could enforce interest-based contracts, was in effect as of August I 983 (Stianse 2004, p.I55).

The first phase of the Islamization of Sudan's banking system took place from 1983 to I985. In this phase, interest was abolished in the country, and the banks faced several difficulties due to the lack of experience in forming Islamic contracts and converting conventional contracts to Islamic contracts (Muhammed et al. 2006). The second phase occurred from I985 to 1989. In 1985, the government passed an act that allowed banks to offer Islamic and conventional products. This continued until the middle of 1989, when the new government issued some laws that led to the elimination of the dual-bank system. The third phase started in 1989 and ended in 2005. This phase marked the real implementation of Islamic banking in the country. The government issued several laws in the 1990's that made Islamic banking the only method of banking allowed in the country. These laws included provisions that established a shariah board within the Central Bank of Sudan and within each bank in the country. In addition, an Islamic deposit-insurance scheme was established in 1996. However, the Islamic banking system in Sudan has actually been a dual system (in 2005) because conventional banks have been allowed to operate in the southern part of the country ${ }^{2}$. Currently, there are 34 banks operating in the country. Furthermore, in comparison to Iran Sudan has been more successful in Islamizing its financial system, Muhammad Taqi Usmani ${ }^{3}$ in 2002 (cited in Al-Hashimi 2013) commented on Sudan success in establishing an Islamic financial system:

"Under the prevailing conditions there is only one country in the world, and that is Sudan, which has implemented the interest-free system. Not only this, all banks and financial institution[s] of Sudan including the central bank, claim that they are operating... [an] interestfree system. They had formed a committee called "Heyath al-Raqabat alShari'ah" in the central bank. This committee is comprised of "Ulama who monitor the functioning of [the] central [bank] and all other banks and financial institutions"

Sudan is lower-middle-income economy, and its economy suffers from macro-economic instability, high rates of poverty, unemployment and dept (Nour 2013). Sudan has a population of approximately 40 million and the majority of the population, about 80 per cent, works in the agricultural sector. In addition, the country suffered from hyperinflation. However, oil production (since 2007) enhanced the economic development of the country.

The motive behind this paper is the scarcity of studies that addressed the determinants of banks' profitability in Iran and Sudan. In addition, according to the best of my knowledge, this is the first paper to compare the profitability of banks in Iran and Sudan.

The rest of the paper organized as follows. Section 2 lists the relative literature and the theoretical development. Section 3 represents the data and methodology while section 4 represents the results analysis. Finally, section 5 represents conclusion.

\footnotetext{
${ }^{2}$ Southern Sudan became an autonomous region in 2005, and in 201 I the region became independent and was renamed the Republic of South Sudan.

${ }^{3}$ One of the highest ranking Muslim scholars in the world.
} 


\section{Literature Review and Theoretical Development}

Capital adequacy, the positive relationship between capital ratio and profitability is explained by signaling theory and expected bankruptcy cost hypothesis. The signaling theory proposes that a higher capital is optimistic signal to the market of the value of an organization. The bankruptcy hypothesis argues that banks in risky environment hold more equity to reduce bankruptcy costs and this will lower interest expenses leading to higher earnings (Berger 1995). This collaborated by the findings of Elgadi (2016), Siddique et al. (2016), Ebrahimi et al. (2015) and Chua (2013).

On the other hand, the risk-return hypothesis suggests that increasing risks, by increasing leverage of the firm, leads to higher expected returns (Obamuyi 2013). Thus, this hypothesis predicts a negative relationship between capital ratio and profitability. The study conducted by Eltahir and Mousa (2016) on suddenness banks' found a negative and significant relation between capital adequacy and profitability. This supported by Wasiuzzaman and Tarmizi (20I0) results, they conducted their study on Malaysian Islamic banks.

It is worth mentioning that other studies such as Lipunga (20I4) did not find a significant relation between profitability and capital adequacy.

This paper will follow the majority of the studies that stated a positive correlation between profitability and capital

ratio.

Loans intensity: literature in general showed that banks' profitability increase with the growth of its loans portfolio as loans are the primary source of revenue in most banks. Among the studies that found a direct relationship between profitability and banks loans are Gul (20II) and Syafri (20I2). However, the increase of banks' loans portfolio will increase banks' risk resulting in lower profitability. Sufian (2009), Hasan and İbrahim (2014) and El-Kassem (2017) study support this. This study like the aforementioned ones will adopt the ratio of loans to total assets to proxy loans intensity, and I predict a negative relationship between loans intensity and banks profitability due to the weak financial, economic and legal environments of Iran and Sudan.

Bank size: the effect of size on banks' profitability is a controversial issue. In one hand, large banks benefit from the economics of scale and economies of scope as banks with large assets are more diversified and less vulnerable to bankruptcy and can raise capital with lower cost leading to higher profitability. This positive relation documented by the findings of Ebrahimi et al. (20I5) and Hooshyari and Moghanloo (20I5). On the other hand, Javaid et al. (20II), Ani et al. (20I2) and Obamuyi (2013) reported a negative association between size and profitability. Literature (Heffernan and Fu 2010; Samad 2015; Ramadan 20I I) also reported insignificant relation between banks' size and profitability.

Operational efficiency: this study will use the ratio of cost to total income to proxy this variable because it reflects the cost of running the bank as percentage of income. Previous studies that examined the relation between operational efficiency and profitability showed mixed results. According to Wasiuzzaman and Tarmizi (2010) the negative relation implies that banks are able to operate at low costs meanwhile the positive relation infers that banks are able to transfer their operating costs to its depositors and borrowers. The study of Elgadi (2016), Siddique et al. (2016), Obeidat et al. (2013) and Wasiuzzaman and Tarmizi (2010) reported a negative correlation between profitability and efficiency. On the other hand, Hooshyari and Moghanloo (20I5) reported a positive association between profitability and efficiency.

Credit risk: there are interrelated relation between banks' profitability and credit risk management as better management will enhance banks profitability. In this study, like Mirzaei and Mirzaei (20II) and Ramadan (20II), the ratio of loan-loss provision to total loans is used to proxy credit risk because it is one of the most putative proxies for credit risk.

Based on this the higher the ratio the poorer the quality of a bank loans portfolio, negative. This negative relation reinforced by the findings of Mustafa et al. (2012) and Ahmad et al. (20I4). On the other hand, the risk-return hypothesis implies that the higher the risk the higher the return and this conformed by Ramadan (20II) study, he found a positive correlation between profitability and credit risk. Ramadan (20II) conclusion confirmed by Syafri (2012).

Liquidity: the relationship between liquidity and banks' profitability explained by expected bankruptcy cost hypothesis and the concept of opportunity cost. The former states the increase of liquidity reduces default probability leading to higher profitability. The study conducted by Oluwasegun and Samuel (2015) and Lartey et al. (2016) supports the expected bankruptcy cost hypothesis argument. On the other hand, liquid assets have low return thus holding high level of liquidity will impose an opportunity cost on banks leading to a lower profitability. The results of Mirzaei and Mirzaei (20II), Shafana (2015) and Dahiyat (2016) support the concept of opportunity cost.

In this study I predicts a negative correlation between profitability and liquidity because developing and under developed countries have loss regulation thus banks hold more liquid assets.

To be noted that this paper will use the ratio of cash and due from banks to total assets as a proxy for liquidity, according to Bonner et al. (2015) cash and due from banks are permanently liquid in all markets. 
Economic growth: Liang and Reichert (2006) concluded that in developing countries the economic development has strong positive effect on the financial sector development. Majority of the studies (Yigermal 2017; Wasiuzzaman and Tarmizi 2010; Beckmann 2007) reported a positive association between economic growth and banks' profitability.

This study similar to Beckmann (2007) will use lagged GDP growth to capture the effect of economic growth on banks profitability because firms and business, especially in countries with fluctuated GDP, need time to flourish (repay its standing debt and obtain new loans).

Interest rate: the changes in interest rate, increasing or decreasing, can affect banks' profitability positively or negatively. In on hand, Owoputi et al. (2014) found a negative relationship between interest rate and profitability and argued that the unanticipated increase in interest rate rise borrowers default and discourage customers from borrowing leading to a lower profitability. His findings supported by Pastory and Marobhe (2015) and Ahmed et al. (2018) study. On the other hand, high interest rate will increase banks' interest margin leading to higher profitability. The study conducted by Obamuyi (20I3), Topak and Talu (2017) and Wambari and Mwangi (2017) confirms this.

This paper will follow the majority of the studies and predicts a positive relationship between interest rate and banks' profitability.

Industry concentration: the studies that investigated the effect of concentration on banks' profitability reported mixed results. The positive relationship between concentration and profitability explained by the structure-conduct-performance (SCP) hypothesis and efficient-structure (ES) theory. The SCP paradigm, also known as market power theory, state that high market concentration decreases the collusion between market participants leading to a monopolistic profit. The ES paradigm postulate that firms with superior management or production technologies have lower costs and therefore higher profit (high efficiency). This positive effect of market concentration on banks' profitability documented by Al-Jarrah (2010) and Ebrahimi et al. (20I5). On the other hand, studies such as Ramadan et al. (20II) and Messai et al. (20I5) reported a negative relationship between banks' profitability and concentration. Boone and Weigand (2000) argued that banks in highly concentrated markets face high competition resulting in lower profitability; they found a negative relationship between concentration and profitablity.

\section{Data, Methodology and Variables \\ 3.I Data and Methodology}

The data used in this study obtained from Bank scope database which is the most comprehensive database for banks in the world as well it standardizes bank's financials to make cross-country comparison between banks more informal.

The study uses unbalanced panel data from 24 banks from Sudan and I6 banks from Iran for the period I992-2008 to compare the factors affecting banks profitability in both countries. The sample represents the majority of the banks in the two countries.

The study adopts a linear regression approach because it is the most used by researchers in the area of performance determinants, specifically panel data. Panel data has several advantages (Hsiao 2007): provide more controlling for individual heterogeneity, less collinearity among the variables, more degrees of freedom and more efficiency; able to control the impact of omitted variables as well as uncovering dynamic relationships; generate more accurate predictions for individual outcomes and simplify computation and statistical inference.

Accordingly, the study employ one-way fixed effect model (unbalanced panel data) to investigate the factors affecting banks' profitability in Iran and Sudan. The fixed effect model according to Baltagi (2005) is an appropriate specification if the study is focusing on a specific set of $\mathrm{N}$ firms and the inference of the study is restricted to the behavior of these sets of firms. Moreover, Hausman test confirms that the fixed effect model is more appropriate than random effect model.

The equation of fixed effect model:

$$
\begin{array}{ll}
\mathrm{Y}_{i t} & =\alpha_{i}+\beta \mathrm{X}_{i t}+\mathrm{u}_{i t} \quad(\mathrm{i}=\mathrm{I}, \ldots, \mathrm{N} ; \mathrm{t}=\mathrm{I}, 2, \ldots, \mathrm{T}) \\
\mathrm{u}_{i t}=\mu_{i}+\mathrm{v}_{i t} &
\end{array}
$$

Where Y represents the dependent variable; $i$ denotes the cross-section dimension (entity) and $t$ denotes the time dimension; $\mathrm{X}$ represents the independent variable; $\beta$ is the regression coefficient of independent variable; $\alpha$ is the intercept; $\mathrm{u}$ is the unique intercept coefficient for each cross-section ( $\mu$ denotes the unobservable individual-specific effect and $v$ denotes the remainder disturbance). 
In the case of fixed effect $\mu_{i}$ are assumed to be fixed parameters to be estimated and the remainder disturbances stochastic with $v_{i t}$ independent and identically distributed $\operatorname{IID}\left(0, \sigma 2_{v}\right)$, and $\mathrm{X}_{i t}$ are assumed independent of the $v_{i t}$ for all $i$ and $t$. (Baltagi 2005).

In addition, the outcomes of Pearson-correlation test which are shown in Table 2 and 3 for Iran and Sudan respectively support the soundness of the regression results. It can be seen that multicollinearity problem are not significant among the variables of the study.

The results of Adjusted R-square for the model were 0.80 and 0.93 for Iran and Sudan respectively indicating the fitness of the model.

\subsection{Variables}

ROA is the independent variable chosen by this study.

\section{Analysis and Discussion \\ 4.I Descriptive Statistics}

Tables 4 and 5 represents the descriptive statistics for Iran and Sudan respectively. The Tables show that Iranian banks are more profitable (mean $=2.45$ ) in comparison to Sudanese banks (mean $=\mathrm{I} .8 \mathrm{I}$ ) and the S.D. is low signifying that there is small difference between banks. Also, Iranian banks have higher loan to asset ratio (mean $=59.36)$ in contrast to Sudanese banks (mean $=39.82$ ) however the S.D is too high in case of Sudan.

On the other hand, Sudanese banks are more liquid (mean $=16.83$ ) while the contrary for Iranian banks (mean $=$ I.02). Moreover, Sudanese banks have higher cost to income ratio (mean $=60.86$ ) and for Iranian banks it is slightly low (mean $=33.67$ ). In addition, loan-loss-provision to total loans ratio is high in Sudanese banks (mean $=4.06$ ) contrary to Iranian banks (mean = I.38), the S.D in case of Sudanese banks is slight high while there is no difference between Iranian banks. The results also showed, generally, that Sudanese banks are bigger in size but there is large difference between banks.

\subsection{Results}

Tables 7 and 8 represent the empirical results of the regression for Iran and Sudan respectively, the results display some differences between banks in Iran and Sudan. Empirical findings show that capital adequacy positively and significantly (I\%) affected banks profitability in Iran and Sudan which supports the signaling theory and expected bankruptcy cost hypothesis. The results are in harmony with Elgadi (2016), Siddique et al. (2016), Ebrahimi et al. (2015) and Chua (20I3) findings. The results also show the same significance but with different sign for loan intensity variable for banks operating in Iran and Sudan. The negative influence indicates that poor economic and financial conditions increase loans default leading to lower profitability. These results are in line with Sufian (2009), Hasan and İbrahim (20I4) and El-Kassem (20I7). In the same vein, operation efficiency correlated negatively and significantly (I\%) with profitability indicating that banks in Iran and Sudan operate at higher cost and the results of this paper reinforced Elgadi (2016), Siddique et al. (2016), Obeidat et al. (2013) and Wasiuzzaman and Tarmizi (2010) conclusion. Liquidity as expected positively affected profitability however the results were significant in case of Iran only at 5 per cent level, the positive effect of liquidity supports bankruptcy cost hypothesis. This outcome is harmonized with Oluwasegun and Samuel (20I5) and Lartey et al. (20I6) study.

In the other direction, credit risk had diverse effect on banks in Iran and Sudan. The results were negative and significant (I\%) for Iran and positive but unmeaningful for Sudan. This could be explained that profitable banks, Iranian banks, tend to hold lower provisions. Also, it can be argued that Iranian banks could raise capital at a low price thus they have lower capital and provisions ratio, see Tables 5 and 6. Size also impacted banks' profitability in Iran and Sudan differently. The effect on Iranian banks was negative and significant at I0 per cent level and positive and significant at 5 per cent level for Sudanese banks. This confirms the presence of economies of scale as large banks more profitable than small banks, see Tables 5 and 6 .

The effect of macroeconomic variables is in line with the expectation. GDP growth positively affected banks' profitability at I per cent level for banks in Iran and Sudan. This confirm Beckmann (2007), Wasiuzzaman and Tarmizi (2010) and Yigermal (2017) findings. Also, real interest rate correlated positively with profitability at I\% and I0\% for Iran and Sudan respectively. Obamuyi (2013), Topak and Talu (2017) and Wambari and Mwangi (20I7) findings support this study conclusion.

Finally, concentration had opposite effect on banks in Iran and Sudan. In case of Iran the effect is negative at 5\% level and positive for Sudanese banks at 10\% level. This indicates that the banking sector in Iran is highly competitive which lower banks' profitability.

\section{Conclusion}

This study examined the determinants of banks' profitability in Iran and Sudan, both banking systems are Islamized. The main results illustrated that capital adequacy, liquidity, GDP growth and real interest rate contributed positively to the profitability of 
banks in Iran and Sudan. On the other hand, loans did not improve banks' profitability. In the same strain, management efficiency lowered banks' profitability thus banks in Iran and Sudan need to improve its management practices to boost its profitability.

The variables that had a diverse effect on banks' profitability in Iran and Sudan are credit risk, size and concentration. Credit risk had negative and significant correlation with profitability for Iranian banks and positive and insignificant for Sudanese banks. Thus, Iranian banks need to improve its risk management practices. Size as well affected Iranian banks negatively and Sudanese banks positively therefore Iranian banks must increase its size to improve its profitability. Coextending, concentration had a negative effect on Iranian banks profitability and the opposite for Sudanese banks.

This study added to the existing literature in the area of Islamic finance, specifically, it compared the factors affecting the financial performance in Iranian and Sudanese banks. However, this study is limited by the time period, I992-2008, as it did not include data beyond 2008. This could motivate researchers to investigate the dynamics that affect banks' profitability in both countries using data beyond 2008 .

\section{References}

Ahmed, A., Rehan, R., Chhapra, I., \& Supro, S. (2018). Interest Rate and Financial Performance of Banks in Pakistan. International Journal of Applied Economics, Finance and Accounting, 2(I), I-7.

Ahmad, F, Tahir, S \& Aziz, B. (20I4). Impact of Loan Loss Provision on Bank Profitability in Pakistan. TIJ's Research Journal of Social Science \& Management, 3(12), 34-4I.

Alharbi, A. (2017). Determinants of Islamic banks' profitability: international evidence. International Journal of Islamic and Middle Eastern Finance and Management, IO(3), 33I-350.

Al-Hashimi, M. (2013). Islamic Banking in Sudan: A Case Study of the Sudanese Islamic Bank', The Pacific Journal of Science and Technology. I4(2), 268-276.

Al-Jarrah, I. (2010). The Market Structure-Profit Relationship in the Jordan's Banking Industry. Dirasat, Administrative Sciences. 37(I), 25I-26I.

Ani, U., Ugwunta, O., Ezeudu, J. \& Ugwuanyi, O. (2012). An empirical assessment of the determinants of bank profitability in Nigeria: Bank characteristics panel evidence. Journal of Accounting and Taxation, 4(3), 38-43.

Beckmann, R. (2007). Profitability of Western European banking systems: Panel evidence on structural and cyclical determinants. Discussion Paper Series 2: Banking and Financial Studies, I7. Deutsche Bundesbank.

Baltagi, B. (2005). Econometric Analysis of Panel Data. John Wiley \& Sons, West Sussex.

Berger, N. (1995). The relationship between capital and earnings in banking. Journal of money credit and Banking. 27(2), 432456.

Bonner, C., Van Lelyveld, I., \& Zymek, R. (2015). Banks' liquidity buffers and the role of liquidity regulation. Journal of Financial Services Research. 48(3), 215-234.

Boone, J., \& Weigand, J. (2000). Measuring Competition in the Dutch Manufacturing Sector: How are Cost Differentials Mapped into Profit Differentials', CPB Working Paper No. I3I, Den Haag.

Chua, Z. (2013). Determinants of Islamic Banks Profitability in Malaysia' Working Paper Series SSRN Number 2276277.

Dahiyat, A. (2016). Does Liquidity and Solvency Affect Banks Profitability? Evidence from Listed Banks in Jordan. International Journal of Academic Research in Accounting, Finance and Management Sciences. 6(I), 35-40.

Ebrahimi, M., Arshadi, A., \& Salimi, S. (2015). Effective Factors on Bank Profitability in Iran. Journal of Money and Economy. IO(I), I07-I29.

El-Kassem, R. (2017). Determinants of Banks' Profitability: Panel Data from Qatar. Open Journal of Accounting. 6, I03-I I I.

Elgadi, E. (2016). Assessing the Financial Performance of Islamic Banking: The case of Sudanese banks', PhD thesis, University of East London, London.

Eltahir, Y., \& Mousa, E. (2016). Profitability of Sudanese Commercial Bank (Panel Data Manipulation). Journal of Economics and Finance. $7(6), 84-89$.

Gul, S., Irshad, F., \& Zaman, K. (20II). Factors affecting bank profitability in Pakistan. The Romanian Economic Journal. $I(39), 6 \mathrm{I}-87$.

Hasan, A., \& İbrahim, K. (20I4). Stock Market Development, Bank Concentration, Ownership Structure, and Bank Performance: Evidence from Turkey. Journal of Economics and Political Economy. I(I), 49-67.

Hsiao, C. (2007). Panel data analysis_-advantages and challenges. Test. I6(I), I-22.

Heffernan, A., \& Fu, X. (2010). Determinants of financial performance in Chinese banking. Applied Financial Economics. 20(20), I585-1600.

Hooshyari, N., \& Moghanloo, A. (2015). Inflation and Profitability: Evidence from Private Banks of Iran. Kuwait Chapter of the Arabian Journal of Business and Management Review. 4(I0), I-5. 
Hosseini, E. (2015). Legislation and Case Law: Provisional Profit in Iran's Banking System: Same Meat, Different Gravy. Electronic Journal of Islamic and Middle Eastern Law. 3, I35-I45.

Javaid S., Anwar J., Zaman K., \& Ghafoor, A. (20II). Determinants of Bank Profitability in Pakistan: Internal Factor Analysis. Journal of Yasar University. 23(6), 3794-3804.

Liang, Y. \& Reichert, A. (2006). The relationship between economic growth and Banking sector development. Banks and Bank Systems. I(2), I9-35.

Lakis, V., \& Baltušytė, D. (2017). iSlAmiC BANkiNG AS AN AlTErNATiVE TO BANkS iN ThE wESTErN COuNTriES. Ekonomika. 96(3), 73-89.

Lartey, V., Antwi, S., \& Boadi, K. (2013). The Relationship between Liquidity and Profitability of Listed Banks in Ghana. International Journal of Business and Social Science. 4(3), 48-56.

Lipunga, A. (2014). Determinants of Profitability of Listed Commercial Banks in Developing Countries: Evidence from Malawi. Research Journal of Finance and Accounting. 5(6), 4I-49.

Messai, A., Gallali, M., \& Jouini, F. (2015). Determinants of Bank Profitability in Western European Countries Evidence from System GMM Estimates. International business research. 8(7), 30-42.

Mirzaei, A., \& Mirzaei, Z. (20II). Bank-specific and macroeconomic determinants of profitability in middle eastern banking. Iranian Economic Review. I5(29),IOI-I28.

Mustafa, A., Ansari, R., \& Younis, M. (2012). Does the Loan Loss Provision Affect the Banking Profitability in Case of Pakistan?. Asian Economic and Financial Review. 2(7),772-783.

Nour, S. (2013). Technological Change and Skill Development in Sudan. Springer, Berlin, Heidelberg.

Obeidat, B., El-Rimawi, S., Maqableh, M., \& Al-Jarrah, I. (2013). Evaluating the profitability of the islamic banks in Jordan. European Journal of Economics, Finance and Administrative Sciences. 56, $27-36$.

Obamuyi, T. 2013. Determinants of banks' profitability in a developing economy: evidence from Nigeria. Organizations and Markets in Emerging Economies. 4(2), 97-I II.

Oluwasegun, J. \& Samuel, A. 2015. The Impact of Liquidity on Nigerian Bank Performance: A Dynamic Panel Approach. Journal of African Macroeconomic Review. 5(2), 318-324.

Owoputi, J., Kayode, O., \& Adeyefa, F. (20I4). Bank specific, industry specific and macroeconomic determinants of bank profitability in Nigeria. European Scientific Journal, ESJ. IO(25), 408-423.

Pastory, D., \& Marobhe, M. (2015). The Determinants of the Commercial Banks Profitability in Tanzania: Panel Evidence. European Journal of Business and Management. 7(13), 212-233.

Ramadan, Z. (20II). Bank-specific determinants of Islamic banks profitability: an empirical study of the Jordanian market. International Journal of Academic Research. 3(6), 73- 80.

Ramadan, I., Kilani, Q. \& Kaddumi, T. (20II). Determinants of bank profitability: evidance from Jordan. International Journal of Academic Research. 3(4), I80-I9I.

Samad, A. (2015). Determinants bank profitability: Empirical evidence from Bangladesh commercial banks. International journal of financial research. 6(3),I73-179.

Shafana, M. (2015). Liquidity and Profitability of Financial Institutions in Sri Lanka. International Journal of Science and Research. 4(6), 589-593.

Siddique, M., Khaleequzzaman, M. \& Ur-Rehman, A. (2016). Determinants of Islamic Banking Industry's Profitability in Pakistan for the Period 2004-2012. Journal of Islamic Business and Management. 6(I), 4I-6I.

Sufian, F. (2009). Factors Influencing Bank Profitability in a Developing Economy. Empirical Evidence from Malaysia. Global Business Review. IO(2), 225-24I.

Syafri (2012). Factors Affecting Bank Profitability in Indonesia. the 2012 International Conference on Business and Management 6 - 7 September 2012 (pp.236-243), SCRIBD, Phuket - Thailand.

Topak, M., \& Talu, N. (2017). Bank Specific and Macroeconomic Determinants of Bank Profitability: Evidence from Turkey. International Journal of Economics and Financial Issues. 7(2), 574-584.

Yigermal, M. (2017). The Determinants of Private Commercial Banks Profitability: In the Case of Selected Ethiopian Private Banks. International Journal of Economic Behavior and Organization. 5(I), 25-35.

Wasiuzzaman, S., \& Tarmizi, H. (2010). Profitability of Islamic Banks in Malaysia: An Empirical Analysis. Journal of Islamic Economics, Banking and Finance. 6(4), 5I-68.

Wambari, K., \& Mwangi, M. (2017). Effect of interest rates on the financial performance of commercial banks in Kenya. International Journal of Finance and Accounting. 2(I), 19-35. 
Appendix

Table 1 The most important historical aspects and events of Islamic banking

The Mit Gharm Savings Bank was established in Egypt in 1963, which greatly influenced the further development of Islamic banking;

The Pilgrim Saving Corporation of Malaysia was established in 1963. Although officially this institution was not considered as a bank, many principles of modern Islamic banking were applied;

The Islamic Development Bank was established in Saudi Arabia in 1975. It was the first Islamic bank that functioned internationally. The bank established its subsidiaries in neighboring countries and its contribution to international trade and exchange was great;

The Dubai Islamic Bank was established as a joint stock company on March 12, 1975. This bank considered the first commercial Islamic banks;

The Islamic Insurance Company of Sudan was established in 1979 - it was the first Islamic insurance company;

The first investment fund that invested only in companies working under the principles of shariah was established in 1986 in Indiana state (US);

Shell MDS in Malaysia established an Islamic bonds equivalent in 1990, which is considered to be the beginning of the Islamic Stock Exchange Market;

The Accounting and Auditing Organization for Islamic Financial Institutions (AAOIFI) was established in 1991. The goal of the organization was to establish general accounting and auditing standards for all Islamic companies;

The Citi Islamic Investment Bank (a subsidiary) in Bahrain was founded in 1996 by Citibank; it provided services to its customers according to shariah requirements. It was the first commercial Western bank that entered the Islamic market with specific products and services;

The Dow Jones Islamic Market Index was introduced in 1999; this index is considered to be the first stock exchange market index and it tracked the return on Islamic investment funds;

The Islamic Financial Services Board was established in 2002; it was the first Islamic organization that regulated the activities of Islamic financial companies;

The Islamic Bank of Britain in 2004 became the first Islamic bank, that expanded beyond the borders of the Muslim world.

Source: adopted from Lakis and Baltušyte (2017) and Alharbi (2015) study.

(C) 
Table 2 Definition, notation and expected sign of the explanatory variables

\begin{tabular}{|c|c|c|c|c|}
\hline & Variables & Measure & Notation & Expected Sign \\
\hline 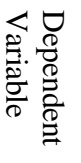 & Profitability & Net profit before tax to total assets & ROA & \\
\hline 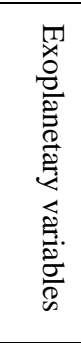 & $\begin{array}{l}\text { Capital adequacy } \\
\text { Loan intensity } \\
\text { Credit risk } \\
\text { Liquidity } \\
\text { Operational efficiency } \\
\text { Size } \\
\text { Economic growth } \\
\text { Industry concentration } \\
\text { Real interest rate }\end{array}$ & $\begin{array}{l}\text { Total equity to total assets } \\
\text { Total loans to total assets } \\
\text { Loan loss provision to total loans } \\
\text { Cash and due from banks to total assets } \\
\text { Cost to income ratio } \\
\text { Total assets } \\
\text { Lag of real GDP growth rate } \\
\text { Herfindahl-Hirschman Index } \\
\text { Real interest rate }\end{array}$ & $\begin{array}{l}\text { EQTA } \\
\text { LON } \\
\text { LLS } \\
\text { LIQ } \\
\text { CI } \\
\text { AST } \\
\text { GDPGR }_{-1} \\
\text { HHI } \\
\text { RI }\end{array}$ & $\begin{array}{l}+ \\
- \\
- \\
- \\
- \\
+ \\
+ \\
+ \\
+\end{array}$ \\
\hline
\end{tabular}

\begin{tabular}{|c|c|c|c|c|c|c|c|c|c|}
\hline & EQTA & LON & LLS & LIQ & $\mathrm{CI}$ & AST & GDPGR-I & HHI & $\mathrm{RI}$ \\
\hline EQTA & 1 & & & & & & & & \\
\hline LON & $-0.30^{* * * *}$ & 1 & & & & & & & \\
\hline LLS & $0.28^{* * *}$ & -0.25 & 1 & & & & & & \\
\hline LIQ & -0.20 & 0.03 & 0.13 & 1 & & & & & \\
\hline CI & $-0.30^{* * * *}$ & 0.14 & -0.27 & 0.24 & 1 & & & & \\
\hline AST & $-0.37^{* *}$ & 0.097 & 0.07 & $0.36^{* *}$ & $0.61^{*}$ & 1 & & & \\
\hline GDPGR $_{\mathrm{t}-1}$ & 0.16 & -0.25 & -0.27 & 0.02 & 0.12 & -0.24 & 1 & & \\
\hline HHI & 0.17 & -0.09 & -0.16 & $-0.32^{* * *}$ & -0.08 & -0.19 & $0.36^{* *}$ & 1 & \\
\hline RI & -0.00 & 0.21 & -0.04 & $-0.28^{*}$ & -0.15 & 0.01 & $-0.34^{* *}$ & $0.63^{* * *}$ & 1 \\
\hline
\end{tabular}


Table 4 Pearson Correlation Statistics for Sudanese banks

\begin{tabular}{llllllllll}
\hline \multicolumn{1}{c}{ EQTA } & LON & LLS & LIQ & CI & AST & GDPGR-I & HHI & RI \\
\hline EQTA & 1 & & & & & & & & \\
LON & $-0.45^{* * *}$ & 1 & & & & & & & \\
LLS & 0.09 & $-0.32^{*}$ & 1 & & & & & & \\
LIQ & 0.07 & $-0.30^{*}$ & $0.38^{* *}$ & 1 & & & & & \\
CI & $-0.30^{*}$ & 0.12 & -0.17 & -0.03 & 1 & & & \\
AST & -0.07 & $0.29^{*}$ & -0.11 & -0.13 & 0.07 & 1 & & \\
GDPGR & -0.07 & 0.16 & -0.07 & -0.09 & -0.07 & 0.31 & 1 & \\
HHI & $-0.30^{*}$ & 0.12 & -0.26 & -0.08 & -0.06 & 0.24 & -0.04 & 1 \\
RI & -0.25 & 0.14 & -0.19 & -0.06 & 0.08 & 0.10 & 0.13 & $0.43^{* * *}$ & 1 \\
\hline
\end{tabular}

Table 5 Descriptive Statistics of Iranian banks

\begin{tabular}{|c|c|c|c|c|c|c|c|c|c|c|c|c|}
\hline & ROA & EQTA & LONTA & LLSPLN & LIQUIDITY & CI & ASSETS05 & \multicolumn{2}{|c|}{ LAG_GDPGR_IRAN } & HHI & RI & \\
\hline Mean & 2.444603 & 12.63457 & 59.35452 & 1.383504 & 1.018888 & 33.674 & 6274.421 & \multicolumn{2}{|l|}{4.915} & 877.42 & -0.6368 & \\
\hline Median & 2.199469 & 7.462973 & 60.97651 & 1.358945 & 0.576803 & 24.26 & 2112.218 & \multicolumn{2}{|l|}{4.6} & 898.91 & 1.31 & \\
\hline Maximum & 11.564 & 41.2453 & 74.40548 & 3.802334 & 9.385351 & 85.11 & 23968.04 & \multicolumn{2}{|l|}{6.3} & 928.2621 & 5.6 & \\
\hline \multicolumn{12}{|l|}{ Minimum } & -6.396 \\
\hline Std. Dev. & 2.109805 & 10.875 & 10.34757 & 0.816754 & 1.7429 & & .16522 & 576 & 1.072871 & & 59.62026 & 4.435506 \\
\hline
\end{tabular}

Table 6 Descriptive Statistics of Sudanese banks

\begin{tabular}{lllllllllll}
\hline Variables & ROA & EQTA & LON & LLS & LIQ & CI & AST & GDPGR-I & HHI & RI \\
\hline Mean & 1.81 & 14.21 & 39.82 & 4.06 & 16.83 & 60.86 & 6408.15 & 7.51 & 5013.19 & 11.29 \\
Med. & 1.69 & 10.94 & 40.39 & 1.23 & 15.86 & 58.48 & 209.12 & 6.4 & 5555.86 & 12.43 \\
Max. & 5.21 & 66.11 & 77.37 & 68.42 & 41.44 & 148.06 & 68724.6 & 15.5 & 8644.92 & 14.66 \\
Min. & -8.96 & 1.96 & 1.67 & 0 & 1.61 & 32.48 & 38.88 & 4.00 & 1358.05 & 7.82 \\
S.D. & 2.32 & 12.23 & 20.36 & 11.26 & 11.32 & 22.15 & 16249.69 & 4.09 & 2498.33 & 2.87 \\
\hline
\end{tabular}

(C) (?) \& Copyright (C) CC-BY-NC 2020, CRIBFB | IJIBFR 
Table 7 Regression results for Iranian bank

\begin{tabular}{|c|c|c|c|}
\hline Variable & Coefficient & t-Statistic & Prob. \\
\hline EQTA & 0.25 & 3.54 & 0.00 \\
\hline LON & -0.05 & -5. & 0 \\
\hline LLS & 0.00 & 0.04 & 0.97 \\
\hline LIQ & 0.02 & 1.18 & 0.26 \\
\hline CI & -0.08 & -17.72 & 0 \\
\hline AST & 0.00 & 2.16 & 0.05 \\
\hline $\mathrm{GDPGR}_{-1}$ & 0.04 & 4.55 & 0.00 \\
\hline RI & 0.03 & 1.83 & 0.09 \\
\hline HHI & 0.00 & 2.10 & 0.06 \\
\hline $\mathrm{C}$ & 3.57 & 3.06 & 0.00 \\
\hline $\begin{array}{lr}\text { Adj. R-square } & 0.93 \\
\text { F-statistic } & 22.28 \\
\text { Prob. (F-statistic) } & 0.00\end{array}$ & & & \\
\hline
\end{tabular}

Table 8 Regression results for Sudanese banks

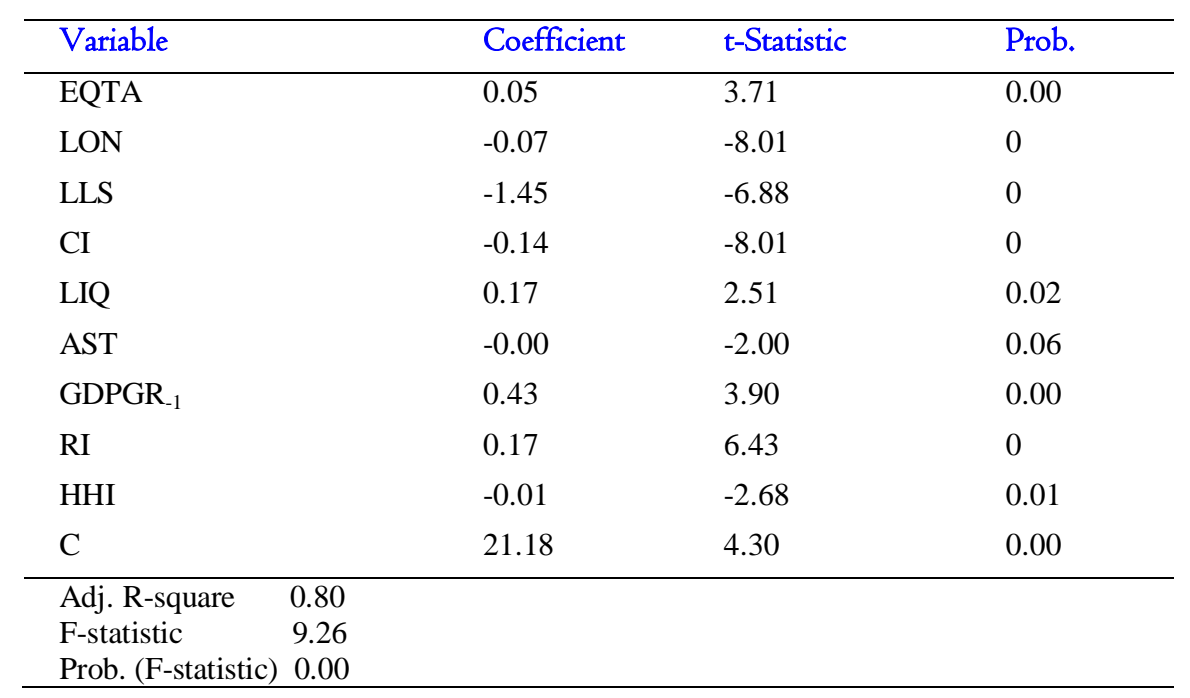

Copyrights

Copyright for this article is retained by the author(s), with first publication rights granted to the journal. This is an open-access article distributed under the terms and conditions of the Creative Commons Attribution license (http://creativecommons.org/licenses/by/4.0/). 